\title{
EXPEDITIOUS EXTRACTION AND SPECTROPHOTOMETRIC DETERMINATION OF PALLADIUM(II) FROM CATALYSTS AND ALLOY SAMPLES USING NEW CHROMOGENIC REAGENT
}

\author{
A. B. Shaikh ${ }^{1}$, U. B. Barache ${ }^{1}$, T. N. Lokhande ${ }^{1}$, G. S. Kamble ${ }^{2}$, \\ M. A. Anuse ${ }^{3}$ and S. H. Gaikwad ${ }^{1, *}$ \\ ${ }^{1}$ Chemistry Research Laboratory, Department of Chemistry, Shri Shivaji Mahavidyalaya, \\ Barshi-413411, (MS) India \\ ${ }^{2}$ Department of Engineering Chemistry, Kolhapur Institute of Technology's, College of \\ Engineering, Kolhapur-416234 (MS) India \\ ${ }^{3}$ Analytical Chemistry Research Laboratory, Department of Chemistry, Shivaji University, \\ Kolhapur-416004 (MS) India \\ *E-mail: rasayanshg@gmail.com
}

\begin{abstract}
A simple, rapid and selective method has been developed for the extractive spectrophotometric determination of palladium(II) using 4-(4'-fluorobenzylideneimino)-3-methyl-5-mercapto-1, 2, 4-triazole, (FBIMMT). In hydrochloric acid medium palladium(II) instantly forms stable yellow colored 1:1 complex with FBIMMT at room temperature, which was well extracted in chloroform. The extracted palladium(II)-FBIMMT species showed absorption maximum at $390 \mathrm{~nm}$ against reagent blank. The molar absorptivity and Sandell's sensitivity of palladium(II)-FBIMMT in chloroform were found to be $5.404 \times 10^{3} \mathrm{~L} \mathrm{~mol}^{-1} \mathrm{~cm}^{-1}$ and $0.0196 \mu \mathrm{g} \mathrm{cm}{ }^{-2}$ respectively. The Beer's law was obeyed up to $17.5 \mu \mathrm{g} \mathrm{mL} \mathrm{m}^{-1}$ of palladium(II). The optimal concentration range for maximum precision was evaluated from Ringbom's plot and was found to be 5 to $17.5 \mu \mathrm{g} \mathrm{mL} \mathrm{m}^{-1}$. To establish the optimum extraction conditions; various experimental parameters such as acidity, reagent concentration, solvents, shaking time, interference of cations and anions have been studied. To determine accuracy and precision of proposed method, determinations were carried out at five identical aliquots. The selectivity of the method was enhanced by the use of masking agents. The stoichiometry of the extracted species was assessed by Job's method, mole ratio method and verified by log-log plot. The present method was successfully applied for the separation and determination of palladium(II) from binary mixtures, multi component synthetic mixtures, synthetic mixtures corresponding to alloys and catalyst.
\end{abstract}

Keywords: Alloy samples, Extraction, FBIMMT, Palladium(II), Spectrophotometry

(C) RASĀYAN. All rights reserved

\section{INTRODUCTION}

Palladium is a rare element having lustrous silvery-white color and belongs to platinum group metals (PGMs). As compared to rest of platinum group metals, palladium has low density and lower melting point. At ordinary temperature, palladium is strongly resistant to corrosion and to the action of acids. Hence palladium and its alloys find extensive applications in various fields like catalysis, jewelry and cosmetic industries, dentistry, production of surgical instruments, electrical contacts and hydrogen storage material. ${ }^{1-7}$ Palladium salts are also used in place of silver compounds in photographic printing papers. ${ }^{8}$ The use of palladium and its alloys in various fields is growing continuously. Besides these applications, palladium causes significant allergic reactions as well as contact dermatitis, stomatitis, and periodontal gum diseases. ${ }^{9-11}$ Therefore, the need arose for the effective extraction and trace level determination of palladium(II). Many analytical techniques such as X-ray fluorescence spectroscopy, ${ }^{12-14}$ atomic absorption spectrophotometry, ${ }^{15-16}$ neutron activation analysis ${ }^{17-18}$ and spectroflurometry ${ }^{19}$ have been used for the 
determination of palladium at microgram level. Though these techniques are highly sensitive, are not selective, involve a number of steps, require sophisticated and expensive instruments. The experts are needed to monitor the instruments. The spectrophotometric methods are simpler and become popular technique for extraction and quantitative determination of palladium(II) and other transition metals. ${ }^{20-22}$

The reported methods suffer from limitations such as maximum absorbance in UV region and less selectivity, some methods are non extractive and require surfactant for full-color development, more equilibration time, synergent, heating of aqueous phase for complexation and have narrow Beer's range. According to Pearson's rule sulfur containing ligands form more stable complexes with PGMs, since sulfur containing ligands are soft bases and PGMs are soft acids. ${ }^{23}$ Extraction and spectrophotometric determination of palladium(II) was reported using several organic reagents, summarized in Table 1. ${ }^{24-39}$ In continuation of our work on the extractive spectrophotometric determination of PGMs, ${ }^{40-43}$ we have synthesized new sulfur containing ligand, FBIMMT and aimed to develop simple, selective and rapid spectrophotometric method for trace level determination of palladium(II).

\section{Apparatus}

\section{EXPERIMENTAL}

Microcontroller based UV-Visible digital spectrophotometer Systronics model-117 (200-1100 nm) with $1 \mathrm{~cm}$ matching quartz cells was used for absorbance measurement. The $\mathrm{pH}$ measurements were made by using Equiptronics digital $\mathrm{pH}$ meter model EQ-615. For weighing purposes an electronic balance Contech, CA-123 was used. Calibrated glass wares were used for volumetric measurements.

Preparation and characterization of 4-(4'-fluorobenzylideneimino)-3-methyl-5-mercapto-1, 2, 4triazole (FBIMMT)

The reagent FBIMMT was prepared by simple condensation of 3-methyl-4-amino-5-mercapto-1, 2, 4triazole $^{44}\left(2.6 \mathrm{~g}, 0.02 \mathrm{~mol} \mathrm{~L}^{-1}\right)$ with 4-fluorobenzaldehyde $\left(2.1 \mathrm{~mL}, 0.02 \mathrm{~mol} \mathrm{~L}^{-1}\right)$. The mixture of 3methyl-4-amino-5-mercapto-1, 2, 4-triazole and 4-fluorobenzaldehyde in $75 \mathrm{~mL}$ of ethanol containing 3 drops of glacial acetic acid was refluxed for 3-4 $\mathrm{h}$. The reaction mixture was poured into ice cold water, filtered and recrystallized from hot 1:2 ethanol. On cooling, white needles were obtained. The scheme-1 shows the reaction for the preparation of FBIMMT.

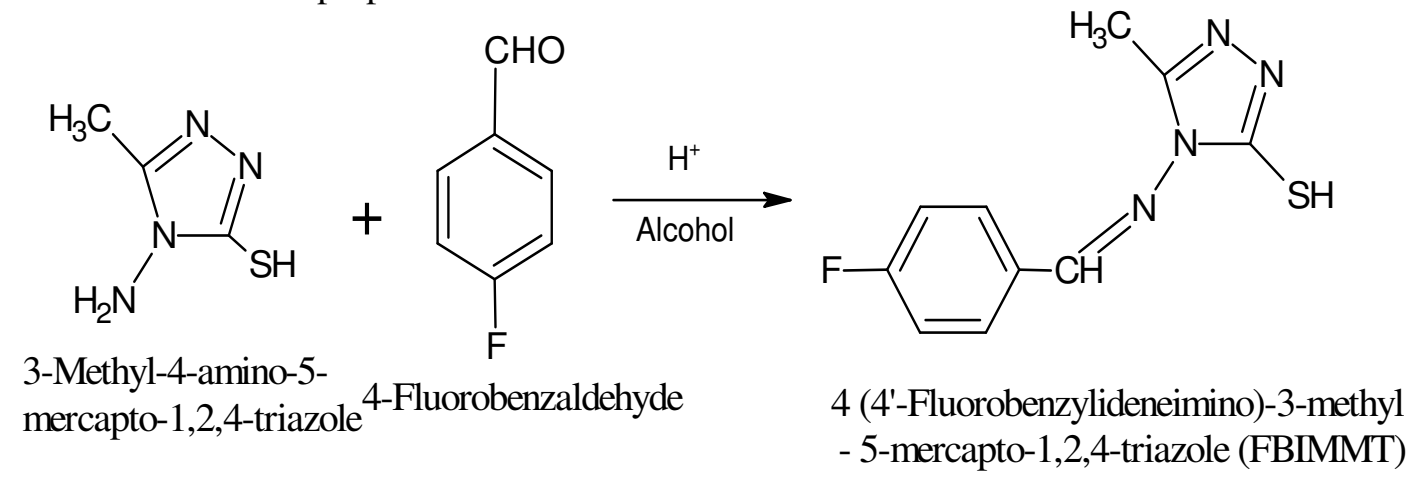

Scheme-1

By using thin layer chromatography, the purity of the FBIMMT was checked. The melting point of the ligand was found to be $190{ }^{\circ} \mathrm{C}$ and its structure was confirmed by using ${ }^{1} \mathrm{H}$ NMR and IR spectra.

${ }^{1} \mathrm{H}$ NMR $\left(400 \mathrm{MHz}, \mathrm{CDCl}_{3}\right): \delta 2.31\left(\mathrm{~s}, 3 \mathrm{H},-\mathrm{CH}_{3}\right), \delta$ 7.01-7.07 (d, 2H, Ar-H), $\delta$ 7.72-7.78 (d, 2H, Ar-H), $\delta 10.34(\mathrm{~s}, 1 \mathrm{H},-\mathrm{N}=\mathrm{CH}), \delta 13.15(\mathrm{~s}, 1 \mathrm{H},-\mathrm{SH}) ; \mathrm{IR}\left(\mathrm{KBr}, \mathrm{cm}^{-1}\right): 2751(\mathrm{SH}), 1171(\mathrm{C}=\mathrm{S}), 1595(\mathrm{HC}=\mathrm{N})$

\section{Standard palladium(II) solution}

A standard stock solution of palladium(II) was prepared by dissolving $1.0 \mathrm{~g}$ palladium chloride $\left(\mathrm{PdCl}_{2}\right.$, Loba chem.) in $1.0 \mathrm{~mol} \mathrm{~L}^{-1} \mathrm{HCl}$ and diluted to $250 \mathrm{~mL}$ in calibrated volumetric flask with distilled water. 
RASĀYAN J. Chem.

Vol. 10 | No. 3 |967 - 980 | July - September | 2017

Table-1: Comparison between present method and reported spectrophotometric methods for the determination of palladium(II)

\begin{tabular}{|c|c|c|c|c|c|c|}
\hline Reagent & $\begin{array}{l}\lambda_{\max } \\
(\mathrm{nm})\end{array}$ & $\begin{array}{l}\text { Acidity }\left(\mathrm{mol} \mathrm{L}^{-1}\right) \\
\text { or } \mathrm{pH}\end{array}$ & $\begin{array}{l}\text { Beer's range } \\
\left(\mu \mathrm{g} \mathrm{mL} \mathrm{mL}^{-1}\right)\end{array}$ & $\begin{array}{c}\text { Molar } \\
\text { absorptivity } \\
\left(\mathrm{L} \mathrm{mol}^{-1} \mathrm{~cm}^{-1}\right)\end{array}$ & Remarks & Ref \\
\hline Hexyl benzimidazolyl sulfide & 452 & $\mathrm{HCl} 0.01-0.1$ & $0.01-0.6$ & $2.08 \times 10^{5}$ & Narrow Beer's range & 24 \\
\hline N,N,N',N'-tetra(2-ethylhexyl) thiodiglycolamide & 300 & $\mathrm{HNO}_{3} 3.0$ & $1.0-15.0$ & $2.29 \times 10^{5}$ & Absorbance in UV region, 5 min. waiting time & 25 \\
\hline 3,4,5-Trimethoxybenzaldehyde thiosemicarbazone & 370 & $\mathrm{HCl} 0.8$ & $1.0-12.0$ & $8.35 \times 10^{4}$ & 2 min. shaking time & 26 \\
\hline Diacetyl monoxime-(p-anisyl)-thiosemicarbazone & 440 & $\mathrm{CH}_{3} \mathrm{COOH} \quad 10.0$ & $0.2-2.0$ & $3.8 \times 10^{4}$ & Non-extractive & 27 \\
\hline$o$-Methoxyphenyl thiourea & 325 & $\mathrm{HCl} 1.0-8.0$ & $0-15.0$ & $3.38 \times 10^{3}$ & Absorbance in UV region & 28 \\
\hline Azure I & 647 & $\mathrm{HCl} 4.0$ & $5.0-20.0$ & - & High interference of $\mathrm{Pt}(\mathrm{IV}), \mathrm{Au}(\mathrm{III}), \mathrm{Hg}(\mathrm{II})$ & 29 \\
\hline 1-Nitroso-2-hydroxy naphthalene-3,6-disulphonate & 510 & $\mathrm{pH} 2.0$ & $0.015-0.3$ & $8.77 \times 10^{5}$ & Heating 5 min. & 30 \\
\hline Picramine-epsilon & 556 & $\mathrm{H}_{2} \mathrm{SO}_{4} 5.0$ & $0.02-0.04$ & $2.01 \times 10^{4}$ & Heating $10 \mathrm{~min}$. & 31 \\
\hline Dahlia violet & 585 & $\mathrm{H}_{2} \mathrm{SO}_{4} 0.02$ & $0.001-0.038$ & - & Heating 10 min. $\left(100^{\circ} \mathrm{C}\right)$ & 32 \\
\hline Thioglycolic acid & 384 & pH 11.0 & $2.4-6.4$ & $2.069 \times 10^{4}$ & Non extractive, interference of many cations & 33 \\
\hline Cefixime & 352 & $\mathrm{pH} 2.6$ & $0.75-16.5$ & $1.224 \times 10^{4}$ & Absorbance in UV region & 34 \\
\hline 3-Hydroxy-2-methyl-1-phenyl-4-pyridone & 345 & $\mathrm{pH} 1.5-3.0$ & $0.28-8.0$ & $1.89 \times 10^{4}$ & Absorbance in UV region, shaking 35 minutes & 35 \\
\hline Benzyl dithiosemicarbazone & 395 & $\mathrm{pH} 2.5$ & $0.25-3.5$ & $3.01 \times 10^{4}$ & Narrow Beer's range & 36 \\
\hline $\begin{array}{l}\text { 3-Methoxysalicylaldehyde-4-hydroxybenzoyl } \\
\text { hydrazone }\end{array}$ & 412 & $\mathrm{pH} 4.5$ & $0.287-4.256$ & $1.03 \times 10^{3}$ & Less sensitive, use of surfactant & 37 \\
\hline $\begin{array}{l}\text { 4-[N'-(4- Imino-2-oxo-thiazolidin-5-ylidene)- } \\
\text { hydrazino]- benzenesulfonic acid } \\
o \text {-Methylphenylthiourea }\end{array}$ & $\begin{array}{l}438 \\
340\end{array}$ & $\begin{array}{l}\mathrm{pH} 5.0 \\
\mathrm{HCl} 0.8\end{array}$ & $\begin{array}{l}0.2-2.2 \\
0.01-15.0\end{array}$ & $\begin{array}{l}7.5 \times 10^{3} \\
2.85 \times 10^{3}\end{array}$ & $\begin{array}{l}\text { Narrow Beer's range, Non extractive } \\
\text { Absorbance in UV region, less sensitive }\end{array}$ & $\begin{array}{l}38 \\
39\end{array}$ \\
\hline $\begin{array}{l}\text { 4-(4'-Fluorobenzylideneimino)-3-methyl-5-mercapto-1, } \\
\text { 2, 4-triazole (FBIMMT)) }\end{array}$ & 390 & $\mathrm{HCl} 0.6-2.0$ & $4.12-17.5$ & $5.404 \times 10^{3}$ & $\begin{array}{l}\text { Rapid, selective, low reagent concentration, } \\
\text { wide Beer's range }\end{array}$ & $\mathrm{PM}$ \\
\hline
\end{tabular}

$\mathrm{PM}=$ Present method 
RASĀYAN J. Chem.

Vol. 10 | No. 3 |967 - 980 | July - September | 2017

The stock solution was standardized gravimetrically by a known method. ${ }^{45}$ The working standard solution of palladium(II) was prepared by proper dilution of the standard stock solution with water.

\section{FBIMMT solution}

The reagent FBIMMT solution $\left(0.01 \mathrm{~mol} \mathrm{~L}^{-1}\right)$ was prepared in chloroform by dissolving $0.236 \mathrm{~g}$ of FBIMMT crystals in $100 \mathrm{~mL}$ calibrated volumetric flask. The fresh reagent solution was used as and when required. Analytical reagent grade chemicals were used throughout the study. The standard solutions of foreign ions were prepared in water by using their salts.

\section{Synthetic mixtures and catalyst samples}

Synthetic samples of the desired composition were prepared by mixing palladium(II) solution with other metal ions solutions in suitable proportions.

The accurately weighed sample of palladium catalyst $(0.1 \mathrm{~g})$ was dissolved in aqua regia, followed by evaporation to moist dryness on a hot plate with the addition of three $5 \mathrm{~mL}$ portions of concentrated hydrochloric acid to remove the oxides of nitrogen. Then it was extracted with $10 \mathrm{~mL}\left(1.0 \mathrm{~mol} \mathrm{~L}^{-1}\right)$ hydrochloric acid, filtered and diluted to $100 \mathrm{~mL}$ with water.

\section{Recommended procedure}

The sample solution ( $1 \mathrm{~mL}$ ) containing $100 \mu \mathrm{g} \mathrm{mL} \mathrm{L}^{-1}$ of palladium(II) was taken and acidity was adjusted to $1.0 \mathrm{M}$ with hydrochloric acid in $25 \mathrm{~mL}$ volumetric flask. The solution was transferred into $125 \mathrm{~mL}$ separating funnel, followed by addition of $10 \mathrm{~mL} 0.01 \mathrm{~mol} \mathrm{~L}^{-1}$ FBIMMT in chloroform. The two phases equilibrated for $10 \mathrm{~s}$. The yellow organic extract was collected over anhydrous sodium sulphate $(1 \mathrm{~g})$ to remove the traces of water. The total volume of the organic phase was made $10 \mathrm{~mL}$ by adding chloroform, if necessary. The absorbance of the extracted yellow complex was measured at $390 \mathrm{~nm}$ against reagent blank. The reagent blank was prepared in the same way without taking palladium(II). A calibration curve was prepared and an unknown amount of palladium(II) was determined from the calibration curve.

The percentage extraction (\%E) and metal distribution ratio (D) were calculated according to equation (1) and (2) respectively. ${ }^{46}$

$$
\begin{aligned}
\% \mathrm{E} & =\frac{[\mathrm{M}]_{\text {org }}}{[\mathrm{M}]_{\text {aq. init }}} \times 100 \ldots \ldots . . .(1) \\
\mathrm{D} & =\frac{[\mathrm{M}]_{\text {org }}}{[\mathrm{M}]_{\text {aq. }}} \quad \ldots \ldots \ldots \ldots(2)
\end{aligned}
$$

Where, $[\mathrm{M}]_{\text {aq.init.. }}=$ initial conc. of metal in the aqueous phase, $[\mathrm{M}]_{\text {org. }}=$ conc. of the metal ion in organic phase after equilibrium and $[\mathrm{M}]_{\mathrm{aq} .}=$ conc. of the metal ion in the aqueous phase after equilibrium

\section{RESULTS AND DISCUSSION}

The 4-(4'-fluorobezylideneimino)-3-methyl-5-mercapto-1,2,4-triazole was synthesized and used to develop an extractive spectrophotometric method for determination of palladium(II) at microgram level. In a hydrochloric acid medium ( 0.6 to $2.0 \mathrm{~mol} \mathrm{~L}^{-1}$ ) FBIMMT in chloroform readily reacts with palladium(II) and forms a yellow colored complex, soluble in chloroform at room temperature. The extracted palladium(II)-FBIMMT species showed absorption maximum at $390 \mathrm{~nm}$ against reagent blank. The extracted complex was stable for more than 24 hours. The method has been employed for extraction and determination of palladium(II) from synthetic mixtures, catalysts and alloy samples. The proposed method offers advantages like a wide range of validity of Beer's law; very less equilibration time, selectivity, reproducibility, and reliability. It does not require heating of aqueous phase, use of synergent and surfactant. Hence the method is rapid reliable, selective and has good potential for its use in the determination of palladium(II) at microgram level. 
RASĀYAN J. Chem.

Vol. 10 | No. 3 |967 - 980 | July - September | 2017

\section{Absorption spectra and spectral characteristics}

Figure-1 shows absorption spectra of the palladium(II)-FBIMMT complex in $1.0 \mathrm{~mol} \mathrm{~L}^{-1}$ hydrochloric acid medium against reagent blank. The absorption measurements were made in the spectral range 380$540 \mathrm{~nm}$. The absorbance curves indicated that the yellow colored palladium(II)-FBIMMT complex in organic phase has an absorbance maximum at $390 \mathrm{~nm}$. All measurements were made at $390 \mathrm{~nm}$ against the reagent blank for further spectrophotometric determination of palladium(II). The optimum conditions for the effective extraction of palladium(II) were established by evaluating the effect of acidity, reagent concentration, choice of solvents, equilibration time and interferences of various foreign ions. The spectral characteristics and precision data are given in Table-2.

\section{Effect of varying experimental conditions Effect of acidity}

Acidity is one of the important parameters which affect on the extraction of metal species. Protonated metal species are stable and therefore enhance the color of metal ligand complex. The different mineral acids such as sulphuric acid, hydrochloric acid and nitric acid in the range 0.1-3.0 mol L-1 were used to investigate the optimum acid concentration for complete extraction of palladium(II)-FBIMMT complex by using $0.01 \mathrm{~mol} \mathrm{~L}^{-1}$ reagent in chloroform. The maximum absorbance was observed in the range 0.6-2.0 mol L-1 hydrochloric acid as shown in Fig.-2. Hence $1.0 \mathrm{~mol} \mathrm{~L}^{-1}$ hydrochloric acid concentration was used conveniently for all the subsequent studies.

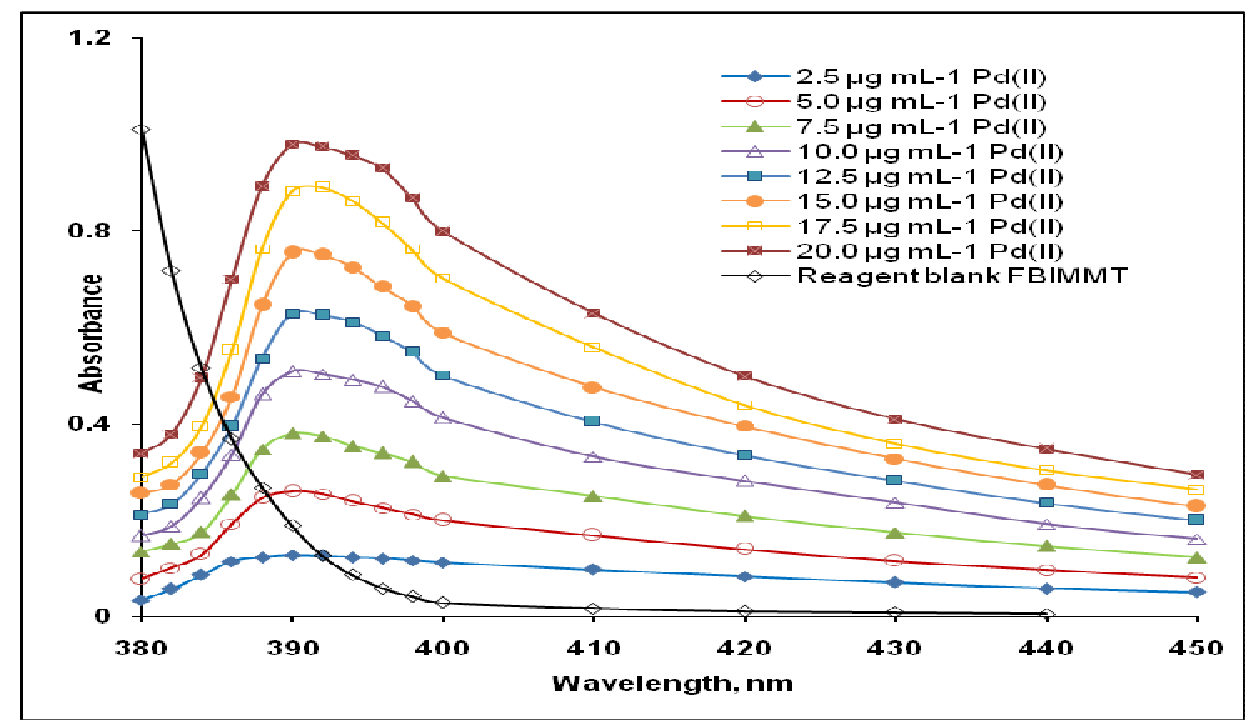

Fig.-1: Absorbance curves for Pd(II)-FBIMMT against a reagent blank and FBIMMT against chloroform. $\operatorname{Pd}(\mathrm{II})=2.5-20 \mu \mathrm{g} \mathrm{mL}{ }^{-1}, \mathrm{HCl}=1.0 \mathrm{~mol} \mathrm{~L}^{-1}$, Equilibration time $=10 \mathrm{~s}$, FBIMMT $=10 \mathrm{~mL} 0.01 \mathrm{~mol} \mathrm{~L}^{-1}$ in chloroform, Wavelength $=380$ to $450 \mathrm{~nm}$.

Table-2: Spectral characteristics and precision data of palladium(II)-FBIMMT complex.

\begin{tabular}{c|c}
\hline Parameters & Optimum range \\
\hline Solvent & Chloroform \\
\hline$\lambda_{\max }$ & $390 \mathrm{~nm}$ \\
\hline Hydrochloric acid concentration & $1.0 \mathrm{~mol} \mathrm{~L}^{-1}\left(0.6-2.0 \mathrm{~mol} \mathrm{~L}^{-1}\right)$ \\
\hline Equilibration time & $10 \mathrm{~s}$ \\
\hline FBIMMT concentration & $0.01 \mathrm{~mol} \mathrm{~L}$ \\
\hline Stability of complex & $>24 \mathrm{~h}$ \\
\hline Beer's law range & $4.13-17.5 \mu \mathrm{g} \mathrm{mL}$ \\
\hline Ringbom's optimum concentration range & $5.0-17.5 \mu \mathrm{g} \mathrm{mL}$ \\
\hline
\end{tabular}


RASĀYAN $J$. Chem.

Vol. 10 | No. 3 | 967 - 980 | July - September | 2017

\begin{tabular}{c|c}
\hline Molar absorptivity & $5.404 \times 10^{3} \mathrm{~L} \mathrm{~mol}^{-1} \mathrm{~cm}^{-1}$ \\
\hline Sandell's sensitivity & $0.0196 \mu \mathrm{g} \mathrm{cm}^{-2}$ \\
\hline Relative standard deviation & $0.621 \%$ \\
\hline Mean recovery & $99.97 \pm 0.62 \%$ \\
\hline Stoichiometry & $1: 1$ \\
\hline
\end{tabular}

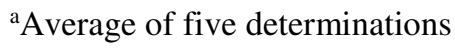

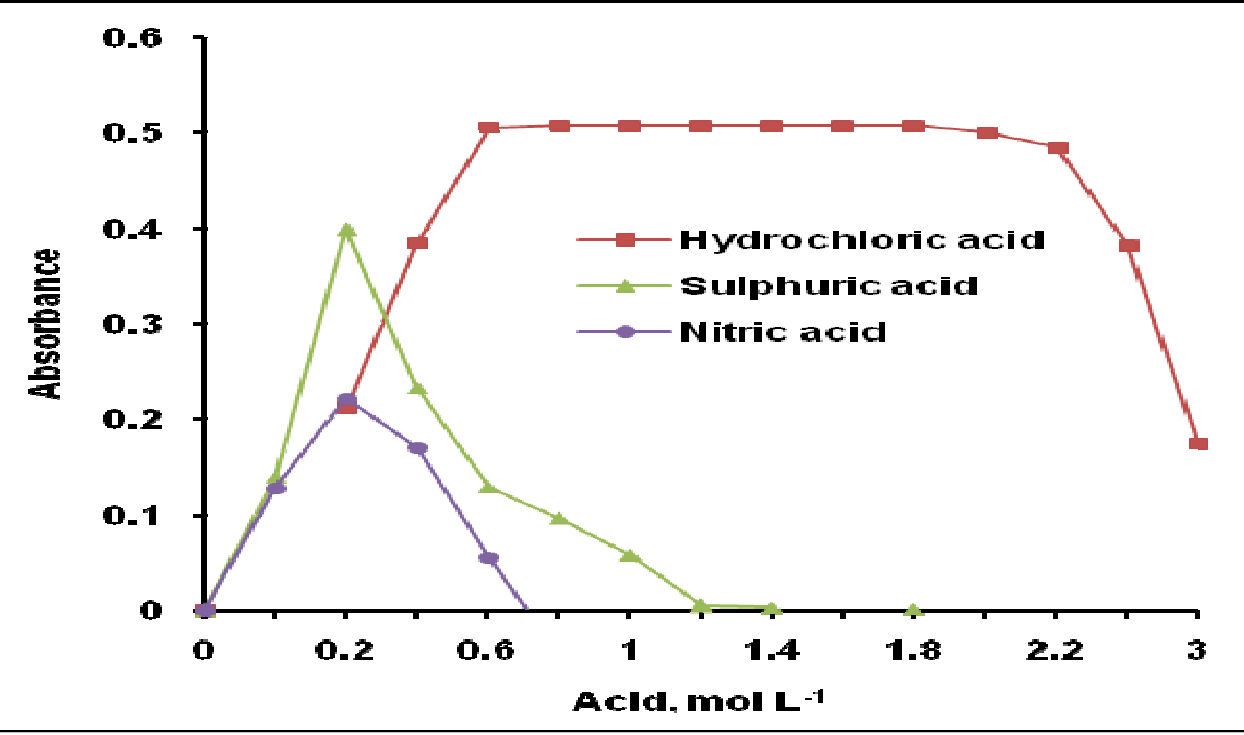

Fig.-2:Effect of acid concentration on the absorbance of Pd(II)-FBIMMT complex.

$\operatorname{Pd}(\mathrm{II})=10 \mu \mathrm{g} \mathrm{mL}^{-1}$, FBIMMT $=10 \mathrm{~mL} 0.01 \mathrm{~mol} \mathrm{~L}^{-1}$ in chloroform, Equilibration time $=10 \mathrm{~s}, \lambda_{\max }=390 \mathrm{~nm}$.

\section{Effect of solvent}

In the extraction of palladium(II), solvent plays very significant role in complexation of palladium(II) with the ligand. Therefore, the effect of various solvents on the extraction of palladium(II) was studied. For this purpose solution of FBIMMT $\left(0.01 \mathrm{~mol} \mathrm{~L}^{-1}\right)$ was prepared in different solvents and the effect of solvents on the percentage extraction at $390 \mathrm{~nm}$ was observed. Results obtained are shown in Fig.-3.

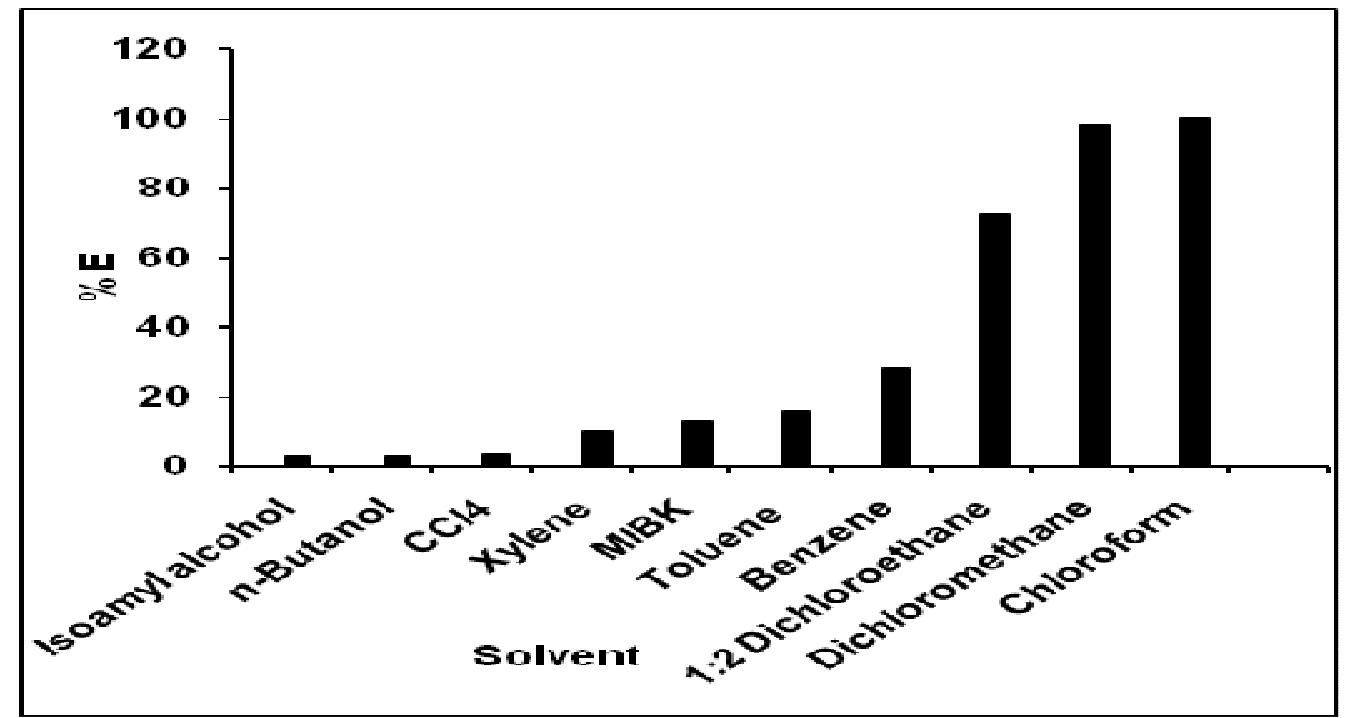

Fig.-3: Effect of solvents on \% extraction of Pd(II)-FBIMMT complex.

$\operatorname{Pd}(\mathrm{II})=10 \mu \mathrm{g} \mathrm{mL}{ }^{-1}, \mathrm{HCl}=1.0 \mathrm{~mol} \mathrm{~L}^{-1}$, FBIMMT $=10 \mathrm{~mL} 0.01 \mathrm{~mol} \mathrm{~L}^{-1}$,Equilibration time $=10 \mathrm{~s}, \lambda_{\max }=390 \mathrm{~nm}$. 


\section{Effect of FBIMMT concentration}

The effect of ligand concentration for the extraction of palladium(II) was studied at $1.0 \mathrm{~mol} \mathrm{~L}^{-1}$ hydrochloric acid. The different molar concentrations of FBIMMT in chloroform in the range 0.0005$0.015 \mathrm{~mol} \mathrm{~L}^{-1}$ were prepared and added to $100 \mu \mathrm{g}$ palladium(II) solutions. The absorbance of the organic phase was measured according to recommended procedure at $390 \mathrm{~nm}$ against respective reagent blank. It was found that $10 \mathrm{~mL} 0.005 \mathrm{~mol} \mathrm{~L}^{-1}$ reagent in chloroform was sufficient to complete complexation and extraction of palladium(II)-FBIMMT complex (Figure 4). Excess concentration of reagent did not affect the extraction and sensitivity of palladium(II) determination, hence $10 \mathrm{~mL}$ of $0.01 \mathrm{~mol} \mathrm{~L}^{-1}$ of reagent in chloroform was used for further studies.

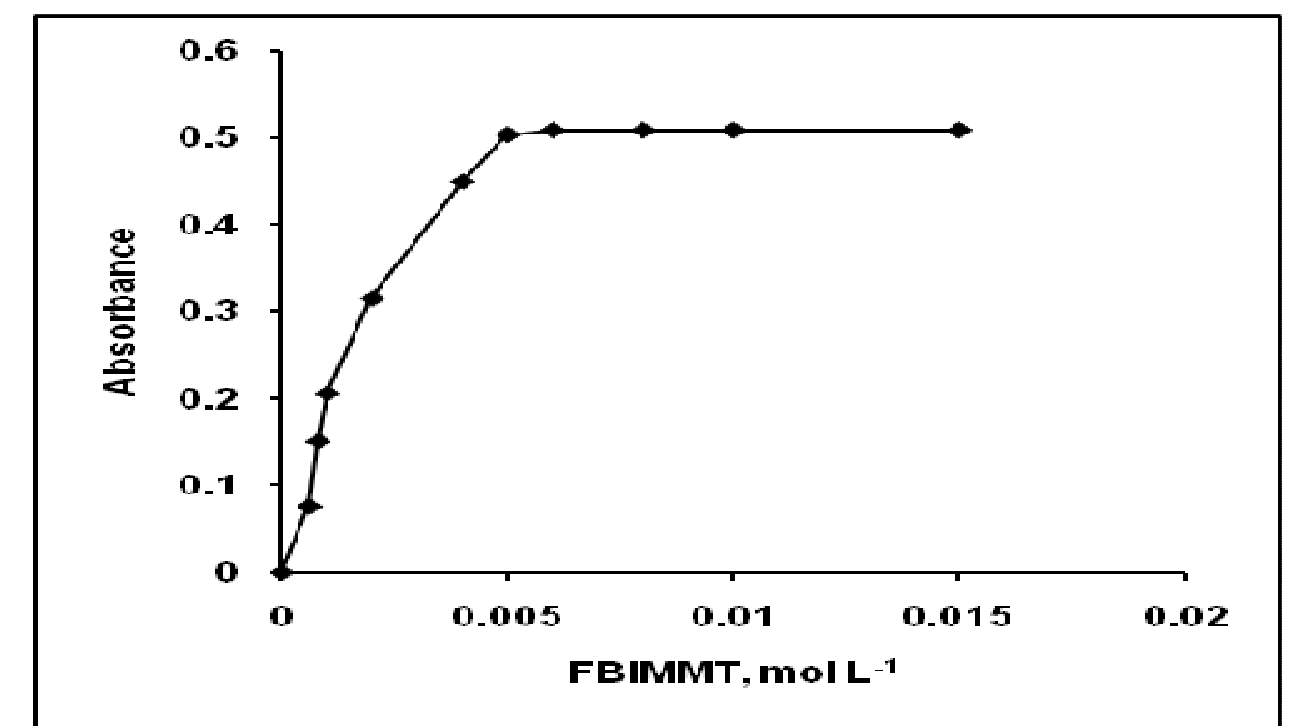

Fig.-4:Effect of reagent concentration on absorbance of Pd(II)-FBIMMT complex.

\section{Effect of shaking time}

$\operatorname{Pd}(\mathrm{II})=10 \mu \mathrm{g} \mathrm{mL}{ }^{-1}, \quad \mathrm{HCl}=1.0 \mathrm{~mol} \mathrm{~L}^{-1}, \mathrm{FBIMMT}$ in $10 \mathrm{~mL}$ chloroform, Equilibration time $=10 \mathrm{~s}$, $\lambda_{\max }=390 \mathrm{~nm}$.

It is often required to investigate the trace amounts of metal ions with high efficiency in a minimum time. Shaking plays an important role in getting an equilibrium between the organic and aqueous phase. For this reason, shaking time varied from $5 \mathrm{~s}$ to $2 \mathrm{~min}$. It was observed that extraction of palladium(II) by FBIMMT $\left(0.01 \mathrm{~mol} \mathrm{~L}^{-1}\right)$ in chloroform was found to be very rapid and occurs in $6 \mathrm{~s}$ quantitatively. Therefore in present investigation $10 \mathrm{~s}$ shaking time was recommended for quantitative extraction of palladium(II) in the organic phase.

\section{Validity of Beer's law and sensitivity}

Determination of palladium(II) at trace level, the absorbance of a solution containing different amount of metal ion under the optimum condition was measured at $390 \mathrm{~nm}$ and a calibration curve was constructed. It was found that at optimized reaction conditions of the palladium(II)-FBIMMT complex obeyed Beer's law up to $17.5 \mu \mathrm{g} \mathrm{mL}^{-1}$ of palladium(II) as shown in Fig.-5, with optimum concentration range 5.0$17.5 \mu \mathrm{g} \mathrm{mL} \mathrm{m}^{-1}$ of the metal as evaluated from a Ringbom's curve, a plot of $\log \mathrm{C}_{[\mathrm{Pd}(\mathrm{II})]}$ versus $\%$ transmittance (Fig.-6). The Ringbom's plot showed the sigmoid curve. The steepest portion of the curve indicates the optimum concentration range where the error is minimal. ${ }^{47}$ The molar absorptivity and Sandell's sensitivity were found to be $5.404 \times 10^{3} \mathrm{~L} \mathrm{~mol}^{-1} \mathrm{~cm}^{-1}$ and $0.0196 \mu \mathrm{g} \mathrm{cm}^{-2}$, respectively. Molar absorptivity and Sandell's sensitivity values suggest that the method is moderately sensitive. ${ }^{48}$

\section{Stoichiometry of the complex}

The composition of palladium(II)-FBIMMT complex was determined by Job's continuous variation method, mole ratio method and was confirmed by log-log plot method. 


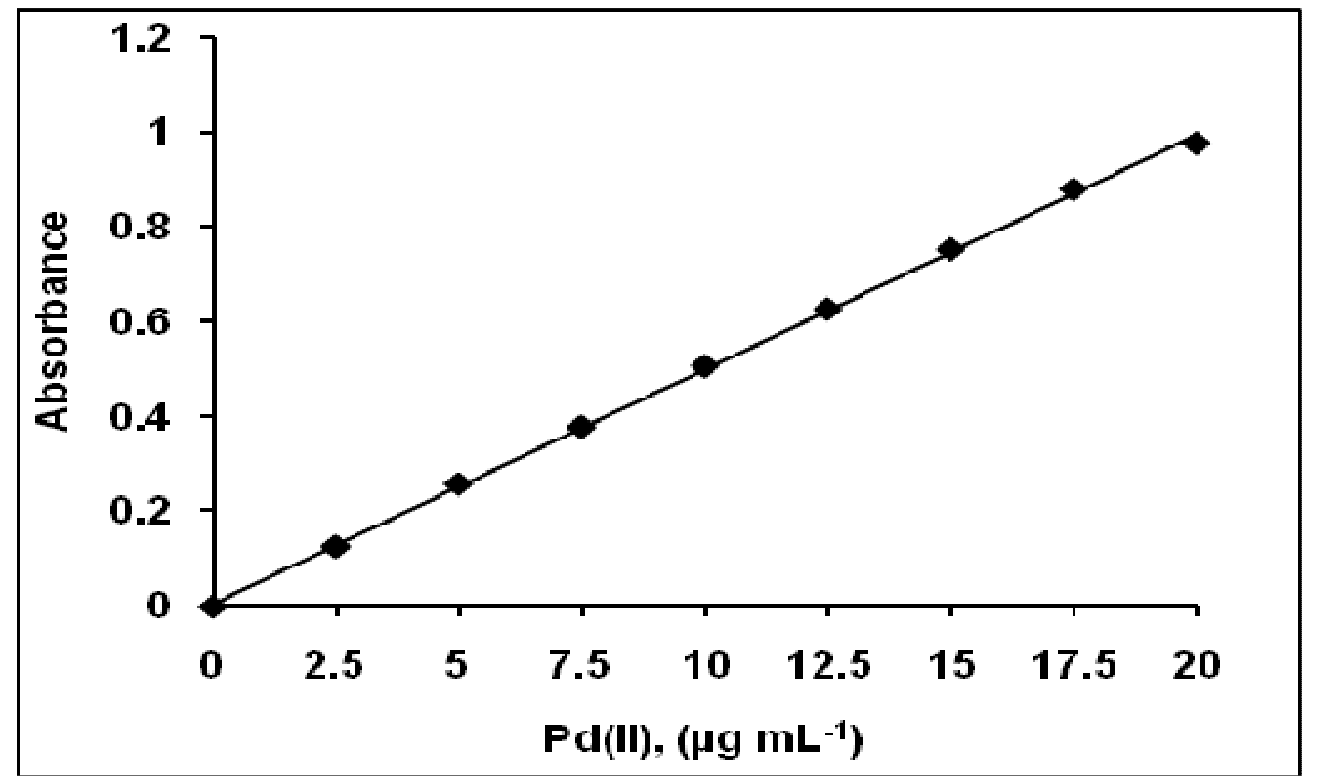

Fig.-5: Validity of Beer's law for Pd(II)-FBIMMT complex.

$\operatorname{Pd}(\mathrm{II})=2.5-20 \mu \mathrm{g} \mathrm{mL}{ }^{-1}, \quad \mathrm{HCl}=1.0 \mathrm{~mol} \mathrm{~L}^{-1}$, FBIMMT $=10 \mathrm{~mL} 0.01 \mathrm{~mol} \mathrm{~L}^{-1}$ in chloroform, Equilibration time $=10 \mathrm{~s}, \quad \lambda_{\max }=390 \mathrm{~nm}$.

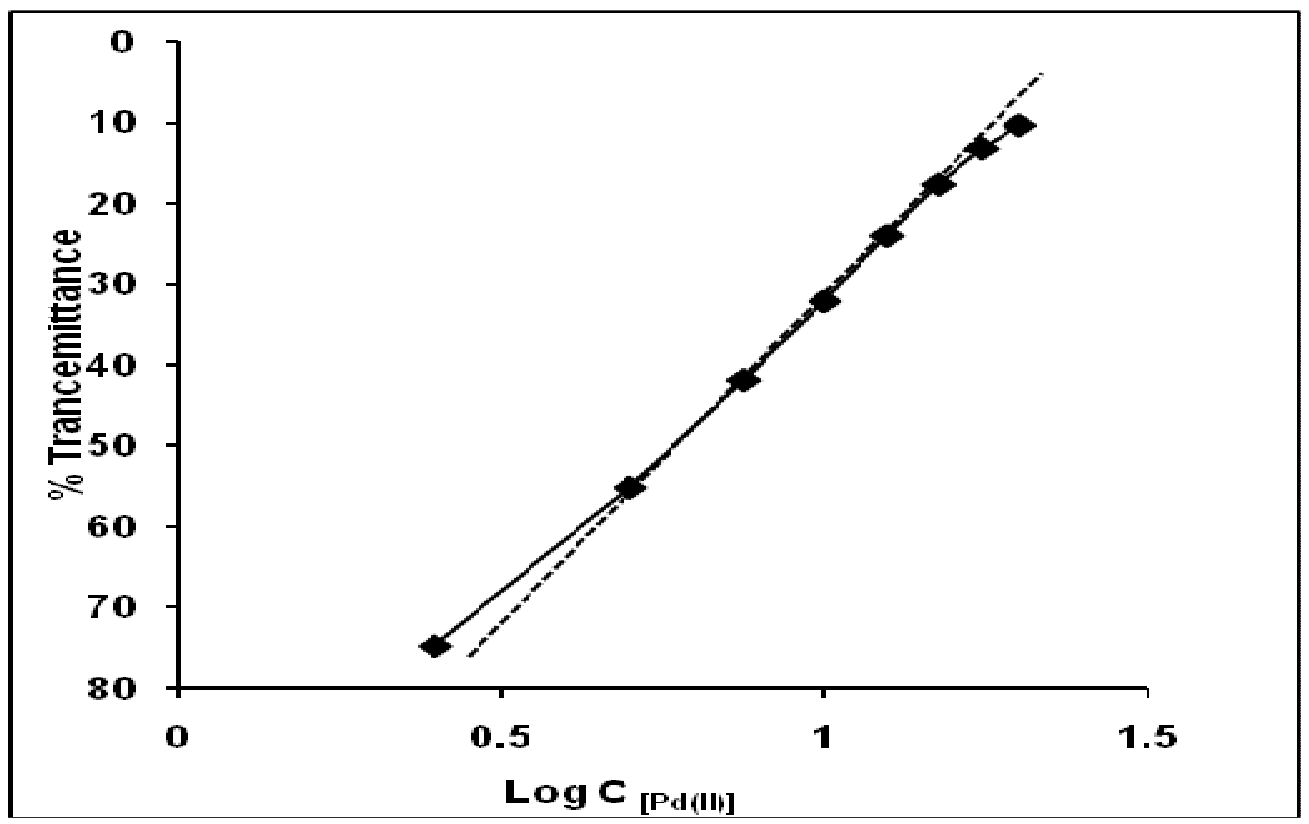

Fig.-6: Ringbom's plot for Pd(II)-FBIMMT complex. $\mathrm{Pd}(\mathrm{II})=2.5-20 \mu \mathrm{g} \mathrm{mL}^{-1}, \quad \mathrm{HCl}=1.0 \mathrm{~mol} \mathrm{~L}^{-1}$, Equilibration time $=10 \mathrm{~s}$, FBIMMT $=10 \mathrm{~mL} 0.01 \mathrm{~mol} \mathrm{~L}^{1}$ in chloroform, $\lambda_{\max }=390 \mathrm{~nm}$.

\section{Job's continuous variation method}

Equimolar solutions of palladium(II) and FBIMMT in chloroform were used to determine the metal to ligand ratio in the complex. The acidity of palladium(II) solution was adjusted to $1.0 \mathrm{~mol} \mathrm{~L}^{-1}$ with hydrochloric acid in a total volume of $25 \mathrm{~mL}$ and the solution was transferred to $125 \mathrm{~mL}$ separating funnel. FBIMMT in chloroform was mixed with complementary proportions containing varying amount of palladium(II). The absorbance of an organic extract was measured at $390 \mathrm{~nm}$ against the reagent blank 
prepared in a similar way without taking palladium(II). The plot of absorbance versus mole fraction $(\mathrm{M} / \mathrm{M}+\mathrm{L})$ indicates that the stoichiometry of palladium(II)-FBIMMT complex is 1:1 (Fig.-7).

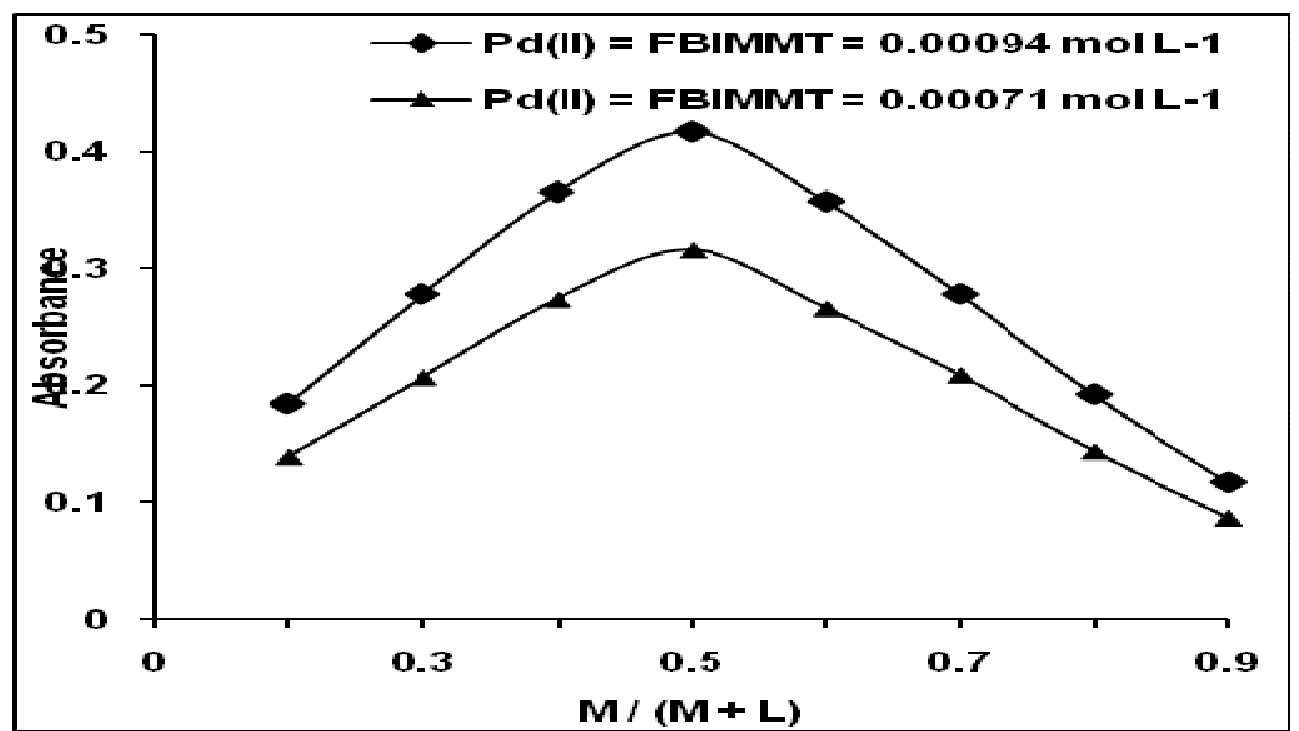

Fig.-7: Job's plot of continuous variation for composition of Pd(II)-FBIMMT complex.

$[\mathrm{M}]=[\mathrm{L}]=0.00094 \mathrm{~mol} \mathrm{~L}^{-1}$ and $0.00071 \mathrm{~mol} \mathrm{~L}^{-1}$, FBIMMT in chloroform, $\mathrm{HCl}=1.0 \mathrm{~mol} \mathrm{~L}^{-1}$, Equilibration time $=10 \mathrm{~s}, \lambda_{\max }=390 \mathrm{~nm}$.

\section{Mole ratio method}

Equimolar solutions of palladium(II) and FBIMMT $\left(9.4 \times 10^{-4} \mathrm{~mol} \mathrm{~L}^{-1}\right)$ were used. Series of solutions were prepared by keeping the concentration of palladium(II) same $(5.0 \mathrm{~mL})$. The acidity of the solution was adjusted to $1.0 \mathrm{~mol} \mathrm{~L}^{-1}$ with hydrochloric acid in $25 \mathrm{~mL}$ volumetric flask. Then this solution was transferred to $125 \mathrm{ml}$ separating funnel. The varying amount of reagent in chloroform $\left(9.4 \times 10^{-4} \mathrm{~mol} \mathrm{~L}^{-1}\right.$, 1.0-10.0 $\mathrm{mL}$ ) were used for extraction of palladium(II)-FBIMMT complex in the organic phase. By adjusting total volume of organic phase to $10 \mathrm{~mL}$ with chloroform, the absorbance was measured at 390 $\mathrm{nm}$ against corresponding reagent blank. The graph of absorbance versus the mole ratio (L/M) showed a break where the palladium(II) to FBIMMT ratio was 1:1 (Fig.-8).



Fig.-8: Mole-ratio method for determination of the composition of the complex.

$\mathrm{Pd}(\mathrm{II})=0.00094 \mathrm{~mol} \mathrm{~L}-1, \quad \mathrm{FBIMMT}=0.00094 \mathrm{~mol} \mathrm{~L}^{-1}$ in chloroform, $\mathrm{HCl}=1.0 \mathrm{~mol} \mathrm{~L}^{-1}$, Equilibration time $=10 \mathrm{~s}, \lambda_{\max }=390 \mathrm{~nm}$. 


\section{Log-log plot method}

The plot of $\log \mathrm{D}_{[\mathrm{Pd}(\mathrm{II})]}$ against $\log \mathrm{C}_{\text {[FBIMMT] }}$ at $0.4 \mathrm{~mol} \mathrm{~L}^{-1}$ hydrochloric acid (Fig.-9), the number of ligand molecules coordinated to the metal ion in the extracted species were confirmed. Where $\mathrm{D}$ denotes the distribution ratio of palladium(II) between two phases and $\mathrm{C}$ is the equilibrium concentration of FBIMMT in the organic phase. The linear plot with slope 0.984 suggests that the Pd(II) to FBIMMT ratio is 1:1. The ligand FBIMMT exists in tautomeric form, ${ }^{49-50}$ it binds with palladium(II) through nitrogen of azomethine group and sulfur of thione group as shown in Scheme-2.

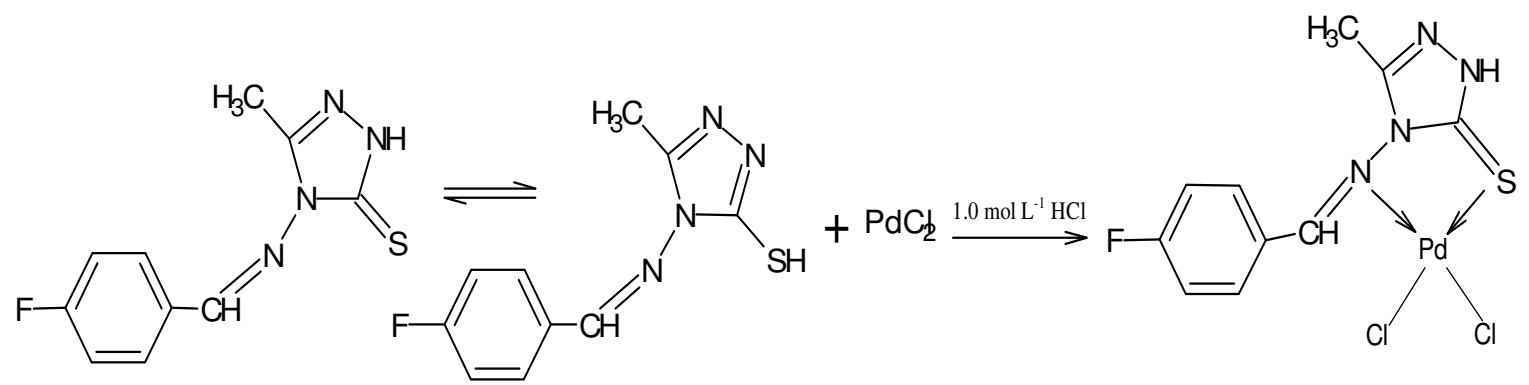

Scheme-2



Fig.-9: Plot of $\log \mathrm{D}_{\text {[Pd(II)] }}$ versus $\log \mathrm{C}_{\text {[FBIMMT] }}$ for determination of the composition of the complex.

$\operatorname{Pd}(\mathrm{II})=10 \mu \mathrm{g} \mathrm{mL} L^{-1}, \mathrm{HCl}=0.4 \mathrm{~mol} \mathrm{~L}^{-1}$, FBIMMT in chloroform, Equilibration time $=10 \mathrm{~s}, \lambda_{\max }=390 \mathrm{~nm}$.

\section{Effect of foreign ions}

The influence of the various foreign ions on the absorbance values of palladium(II)-FBIMMT complex was studied to find selectivity of proposed method. The large amounts of commonly associated cations and anions do not interfere with absorbance values. The tolerance limit of the ions showed minimum deviation $( \pm 2 \%)$ in absorbance. By using suitable masking agents, the interference of some cations was removed (Table-3).

\section{Precision and accuracy}

The precision and accuracy of the present method were evaluated by analyzing five identical solutions containing $100 \mu \mathrm{g}$ palladium(II) by recommended procedure. The average of five determinations is 99.97 and the variation from mean was found to be \pm 0.621 at $95 \%$ confidence limit. These values indicate that the method has good accuracy and reproducibility. 
RASĀYAN J. Chem.

Vol. 10 | No. 3 |967 - 980 | July - September | 2017

Table-3: Effect of foreign ions on the extractive spectrophotometric determination of Pd(II).

\begin{tabular}{l|c}
\hline \multicolumn{1}{c|}{ Foreign ions (Anions and cations) } & Amount tolerated (mg) \\
\hline Oxalate, citrate, bromide, thiocyanate, acetate, and tartarate & 100 \\
\hline Iodide, Fluoride, Succinate and Sulphate ions & 50 \\
\hline $\mathrm{Ba}(\mathrm{II}), \mathrm{Ca}(\mathrm{II}), \mathrm{Mg}(\mathrm{II}), \mathrm{Cd}(\mathrm{II}), \mathrm{Sb}(\mathrm{III}), \mathrm{Al}(\mathrm{III})$ and $\mathrm{V}(\mathrm{V})$ & 5.0 \\
\hline $\mathrm{Co}(\mathrm{II}), \mathrm{Mn}(\mathrm{II}), \mathrm{Ni}(\mathrm{II}), \mathrm{Pb}(\mathrm{II}), \mathrm{Zn}(\mathrm{II}), \mathrm{Fe}(\mathrm{III})$ and $\mathrm{Tl}(\mathrm{III})$ & 4.0 \\
\hline $\mathrm{Ir}(\mathrm{III})$ and $\mathrm{Bi}(\mathrm{III})$ & 2.0 \\
\hline $\mathrm{La}(\mathrm{III})$ and $\mathrm{Hg}(\mathrm{II})$ & 1.0 \\
\hline $\mathrm{Ag}(\mathrm{I})^{\mathrm{a}}, \mathrm{Sn}(\mathrm{II})^{\mathrm{b}}, \mathrm{Cu}(\mathrm{II}), \mathrm{Ga}(\mathrm{III}), \mathrm{In}(\mathrm{III}), \mathrm{Ru}(\mathrm{III}), \mathrm{Rh}(\mathrm{III}), \mathrm{Pt}(\mathrm{IV}), \mathrm{U}(\mathrm{VI}), \mathrm{Zr}(\mathrm{IV})^{\mathrm{b}}$ & 0.5 \\
$\mathrm{and}_{\mathrm{O}}(\mathrm{VIII})$ & 0.1 \\
\hline $\mathrm{Se}(\mathrm{IV})$ and Te$(\mathrm{IV})$ & \\
\hline $\mathrm{Au}(\mathrm{III})^{\mathrm{c}}$ & \\
\hline${ }^{\mathrm{a}}$ Masked with $50 \mathrm{mg}$ iodide, ${ }^{\mathrm{b}}$ Masked with $50 \mathrm{mg}$ oxalate, ${ }^{\mathrm{c}}$ Masked with $50 \mathrm{mg}$ thiocyanate.
\end{tabular}

\section{Applications}

\section{Separation and determination of palladium(II) from synthetic mixtures}

To check selectivity of the present method, the separation and determination of palladium from associated metal ions were carried out following the recommended procedure. The proposed method permits separation of palladium(II) from associated metal ions such as $\mathrm{Cu}$ (II), $\mathrm{Mg}$ (II), $\mathrm{Co}$ (II), $\mathrm{Ni}(\mathrm{II}), \mathrm{Mn}$ (II) $\mathrm{Pt}(\mathrm{IV})$ and Os(VIII) due to difference in the complexation conditions for each metal ions. Under the set condition of recommended procedure, associated metal ions were found quantitatively in the aqueous phase. Firstly aqueous phase was evaporated just to dryness. The residue was treated with concentrated hydrochloric acid repeatedly followed by evaporation. Then this moist dry salt was dissolved in water and diluted to suitable volume. The metal ions were estimated by standard methods. ${ }^{51-53}$ The results are reported in Table-4.

Furthermore, to evaluate the applicability of proposed method, the multi component synthetic mixtures were analyzed by employing recommended procedure. The results obtained were in conformity with theoretical amount of palladium(II) taken ( Table-5).

\section{Determination of palladium(II) in catalysts}

The utility of proposed method was also assessed by determination of palladium(II) in palladium catalyst samples. An appropriate aliquot (catalyst solution) was taken for the analysis of palladium content and analysis was carried out by recommended procedure. The results obtained by present method were in good agreement with the certified values (Table-6).

To evaluate the analytical applicability of the present method, the synthetic alloy samples were prepared based on the composition of some alloys such as low melting dental alloy, jewelry alloy, stibiopalladinite minerals, okey alloy, golden colored silver alloy and $\mathrm{Pd}-\mathrm{Cu}$ alloy. The amount of palladium(II) was determined by using recommended procedure from synthetic mixtures of these alloy samples. The results obtained were summarized in Table-7.

Table-4: Separation and determination of palladium(II) from binary synthetic mixtures

\begin{tabular}{c|c|c|c|c|c}
\hline Metal ions & Amount taken $(\mu \mathrm{g})$ & Average recovery $(\%)$ & ${ }^{*}$ RSD $(\%)$ & Chromogenic ligand & Ref. \\
\hline $\mathrm{Pd}(\mathrm{II})$ & 100 & 99.95 & 0.62 & FBIMMT & - \\
\hline $\mathrm{Cu}(\mathrm{II})$ & 100 & 99.34 & 0.48 & NBIMMT & 51 \\
\hline $\mathrm{Pd}(\mathrm{II})$ & 100 & 99.57 & 0.33 & FBIMMT & - \\
\hline $\mathrm{Mg}(\mathrm{II})$ & 100 & 99.30 & 0.84 & Titan yellow & 52 \\
\hline $\mathrm{Pd}(\mathrm{II})$ & 100 & 99.38 & 0.54 & FBIMMT & - \\
\hline $\mathrm{Co}(\mathrm{II})$ & 100 & 99.58 & 0.36 & Thiocyanate & 52 \\
\hline $\mathrm{Pd}(\mathrm{II})$ & 100 & 99.40 & 0.56 & FBIMMT & - \\
\hline $\mathrm{Ni}(\mathrm{II})$ & 100 & 99.70 & 0.36 & DMG & 52 \\
\hline $\mathrm{Pd}(\mathrm{II})$ & 100 & 99.15 & 0.85 & FBIMMT & - \\
\hline $\mathrm{Mn}(\mathrm{II})$ & 100 & 99.87 & 0.33 & Permanganate & 52 \\
\hline
\end{tabular}


RASĀYAN J. Chem.

Vol. 10 | No. 3 |967 - 980 | July - September | 2017

\begin{tabular}{c|c|c|c|c|c}
\hline $\operatorname{Pd}($ II) & 100 & 99.65 & 0.85 & FBIMMT & - \\
\hline $\mathrm{Pt}(\mathrm{IV})$ & 100 & 99.80 & 0.28 & Tin Chloride & 52 \\
\hline $\mathrm{Pd}(\mathrm{II})$ & 100 & 99.61 & 0.29 & FBIMMT & - \\
\hline Os(VIII) & 100 & 99.74 & $0 . .37$ & 2-NBATCH & 53 \\
\hline
\end{tabular}

*Average of five determinations; ${ }^{*}$ Relative standard deviation

Table-5: Determination of palladium(II) from multi component synthetic mixtures

\begin{tabular}{l|c|c}
\hline Composition $(\mu \mathrm{g})$ & Recovery*(\%) & ${ }^{*} \mathrm{RSD}(\%)$ \\
\hline $\mathrm{Pd}(\mathrm{II}), 100 ; \mathrm{Fe}(\mathrm{III}), 1000 ; \mathrm{Cu}(\mathrm{II}), 1000$ & 99.8 & 0.11 \\
\hline $\mathrm{Pd}(\mathrm{II}), 100 ; \mathrm{Ni}(\mathrm{II}), 1000 ; \mathrm{Co}(\mathrm{II}), 1000$ & 99.7 & 0.10 \\
\hline $\mathrm{Pd}(\mathrm{II}$,$) 100; \mathrm{Fe}(\mathrm{III}), 1000 ; \mathrm{Cu}(\mathrm{II}), 1000 ; \mathrm{Ni}(\mathrm{II}), 1000 ; \mathrm{Co}(\mathrm{II}), 1000$ & 99.8 & 0.05 \\
\hline $\mathrm{Pd}(\mathrm{II}), 100 ; \mathrm{Os}(\mathrm{III}), 300$ & 99.9 & 0.07 \\
\hline $\mathrm{Pd}(\mathrm{II}), 100 ; \mathrm{Ru}(\mathrm{III}), 300$ & 99.8 & 0.16 \\
\hline $\mathrm{Pd}(\mathrm{II}), 100 ; \mathrm{Rh}(\mathrm{III}), 300$ & 99.8 & 0.12 \\
\hline $\mathrm{Pd}(\mathrm{II}), 100 ; \mathrm{Ir}(\mathrm{III}), 300$ & 99.7 & 0.14 \\
\hline $\mathrm{Pd}(\mathrm{II}), 100 ; \mathrm{Pt}(\mathrm{IV}), 100$ & 99.9 & 0.07 \\
\hline
\end{tabular}

*Average of five determinations; ${ }^{*}$ Relative standard deviation

Table-6: Determination of palladium(II) in catalysts

\begin{tabular}{|c|c|c|c|}
\hline Catalyst sample & $\begin{array}{l}\mathrm{Pd}(\mathrm{II}) \text { taken } \\
\left(\mu \mathrm{g} \mathrm{mL} \mathrm{L}^{-1}\right)\end{array}$ & $\begin{array}{c}\text { Recovery* } \\
(\%)\end{array}$ & $\begin{array}{c}{ }^{~} \mathrm{RSD} \\
(\%)\end{array}$ \\
\hline Lindlar hydrogenation catalyst $\left(\mathrm{Pd}\right.$ on $\left.\mathrm{CaCO}_{3} 5 \%\right)$ & 100 & 99.75 & 0.37 \\
\hline Lindlar hydrogenation catalyst $\left(\mathrm{Pd}\right.$ on $\left.\mathrm{CaCO}_{3} 10 \%\right)$ & 100 & 99.49 & 0.56 \\
\hline Hydrogenation catalyst $\left(\mathrm{Pd}\right.$ on $\left.\mathrm{BaSO}_{4} 10 \%\right)$ & 100 & 99.48 & 0.55 \\
\hline Hydrogenation catalyst ( $\mathrm{Pd}$ on asbestos $5 \%$ ) & 100 & 99.63 & 0.42 \\
\hline Hydrogenation catalyst (Pd on asbestos $10 \%)$ & 100 & 99.56 & 0.45 \\
\hline
\end{tabular}

*Average of five determinations "Relative standard deviation

Table-7: Determination of palladium(II) from synthetic mixtures of corresponding alloys

\begin{tabular}{c|c|c|c}
\hline Alloy & $\begin{array}{c}\text { Composition } \\
(\%)\end{array}$ & $\begin{array}{c}\text { Recovery* } \\
(\%)\end{array}$ & $\begin{array}{c}\text { RSD } \\
(\%)\end{array}$ \\
\hline Low melting dental alloy & $\mathrm{Pd}, 34 ; \mathrm{Au}^{\mathrm{a}}, 10 ; \mathrm{Co}, 22 ; \mathrm{Ni}, 34$ & 99.62 & 0.37 \\
\hline Jewellery alloy & $\mathrm{Pd}, 50 ; \mathrm{Au}^{\mathrm{a}}, 50$ & 99.79 & 0.16 \\
\hline Stibiopalladinite minerals & $\mathrm{Pd}, 75 ; \mathrm{Sb}, 25$ & 99.89 & 0.15 \\
\hline Okey alloy & $\mathrm{Pd}, 18 ; \mathrm{V}, 9.1 ; \mathrm{Pt}, 18.2 ; \mathrm{Ni}, 54.2$ & 99.59 & 0.41 \\
\hline Golden coloured silver alloy & $\mathrm{Pd}, 25.5 ; \mathrm{Cu}, 18 ; \mathrm{In}, 21 ; \mathrm{Ag}^{\mathrm{b}}, 35$ & 99.85 & 0.18 \\
\hline Pd-Cu alloy & $\mathrm{Pd}, 60 ; \mathrm{Cu}, 40$ & 99.72 & 0.26 \\
\hline
\end{tabular}

*Average of five determinations; "Relative standard deviation

${ }^{\mathrm{a}}$ Masked with $50 \mathrm{mg}$ thiocyanate, ${ }^{\mathrm{b}}$ Masked with $50 \mathrm{mg}$ iodide

\section{ACKNOWLEDGEMENT}

One of the authors, A. B. Shaikh highly acknowledges University Grants Commission, New Delhi, for the teacher fellowship under faculty development program (FDP). The authors are also thankful to Principal Dr. P. R. Thorat for providing necessary facilities and Dr. V. M. Gurame for valuable suggestions during this work.

\section{REFERENCES}

1. C. Drahl, Chemical and Engineering News, 86, 53 (2008).

2. J. Tsuji, Synthesis, 1990, 739 (1990).

3. R.W. Hesse, Jewellery Making through History: an Encyclopedia, Greenwood Publishing group, 
RASĀYAN $J$. Chem.

Vol. 10 | No. 3 | 967 - 980 | July - September | 2017

London, p.146 (2007).

4. P. Colon, N. Pradelle-plasse and J. Galland, Dental Material, 19, 232 (2003).

5. R. Rushforth, Platinum Metal Rev., 48, 30 (2004).

6. Harper, A. Charls, Passive Electronic Component Hand Book, 2nd ed.; McGraw-Hill professional, New York, P-580 (1997).

7. W. Grochala, P. P. Edwards, Chem. Rev., 104, 1283 (2004).

8. M. Ware, Platinum Metal Rev., 49, 190 (2005).

9. J. A. Marcusson, Contact Dermatitis, 34, 320 (1996).

10. D. Downey, Contact Dermatitis, 21, 54 (1989).

11. P. Koch, Hans-peter Baum, Contact Dermatitis, 34, 253 (1996).

12. E. Margui, K. Van Meel, R. Van Grieken, A. Buendia, C. Fontas, M. Hindalgo and I. Queralt, Anal. Chem., 81, 140 (2009).

13. F. T. Wybenga and A .Strasheim, Appl. Spectry., 20, 247 (1966).

14. K. Van Meel, A. Smekens, M. Behets, P. Kazandjian and R. Van Grieken, Anal. Chem., 79, 6383 (2007).

15. G. Absalan, A. Safavi and A. Massoumi, Microchem. J., 37, 212 (1988).

16. S. Tokalioglu, T. Oymak and S. Kartal, Analytica Chimica Acta, 511, 255 (2004).

17. M. Schwarzer, M. Schuster and R. Von-Henting, Fresenius J. Anal. Chem., 368, 240 (2000).

18. S. Lahiri, S. Day, T. K. Baidya, M. Nandy, D. Basu and N. R. Das, Appl. Radiat. Isot., 48, 549 (1997).

19. A. F. El-Walily, S. F. Belal and R. S. Bakry, J. Pharma. Biomed. Anal., 14, 561 (1996).

20. K. Aruna Bai, G. V. S. Vallinath, K. B. Chandrasekhar and N. Devanna, Rasayan J. Chem., 3, 467 (2010).

21. R. S. Lokhande, S. P. Janwadkar, S. Pitale, S. Kulkarni and S. Patil, Rasayan J. Chem., 4, 609 (2011).

22. K. Ravindhranath, Rasayan J. Chem., 5, 38 (2012).

23. R. G. Pearson, J. Am. Chem. Soc., 85, 3533 (1963).

24. Z. Huang, S. Wang, X. Yang, Q. Wei and C .Jing, Chemia Analityczna, 53, 347 (2008).

25. R. Ruhela, J. N. Sharma, B.Tomar, R. C. Hubli and A. K. Suri, Talanta, 85, 1217 (2011).

26. A .M. A. Khadar and K. S. Prasad, Turk. J. Chem., 20, 222 (1996).

27. A.Varghese and A. M. A. Khadar, Indian J. Chem. Technol., 18, 177 (2011).

28. S. Kuchekar, R. Naval and S. H. Han, S. Afr. J. Chem., 67, 226 (2014).

29. M. Zeydvandi and N. Pourreza, J. Anal. Chem., 61, 744 (2006).

30. D. Bilba, C. Paduraru and L. Tofan, Microchim. Acta, 144, 97 (2004).

31. Y. V. Demin, L. V. Borisova and I. D. Troshkina, J. Anal. Chem., 63, 135 (2008).

32. B. Du, T. Yan, S. Y. Liu, J. Wand and Q. Wei, J. Anal. Chem, 62, 794 (2007).

33. B. Mathew and D. Innocent, Asian J. Chem., 22, 7551 (2010).

34. S. N. H. Azmi, B. Iqbal, B. H. K. Ruquishi, S. A. M. A. Sayabi, N. M. K. A. Quraini and N. J. Rahman, Association of Arab University Basic and Applied Science, 19, 29 (2016).

35. V. Vojkovic and V. Druskovic, Croatica Chemica Acta, 76, 87 (2003).

36. B. K. Reddy, K. J. Reddy, J. R. Kumar, A .K. Kumar and A. V. Reddy, Anal. Sci., 20, 925 (2004).

37. M. R. Rao and K. B. Chandrasekhar, Eur. J. Applied Eng. Scient. Res., 1, 48 (2012).

38. L. Lozynska, O. Tymoshuk and T. Chaban, Acta Chim. Slov., 62, 159 (2015).

39. Y. S. Shelar, H. R. Aher, S. R. Kuchekar and S. H. Han, Bulgarian Chemical Communication, 45, $172(2012)$.

40. P. T. Gojare, S. H. Gaikwad and M. A. Anuse, Res. J. Chem. Environ., 5, 51 (2001).

41. S. H. Gaikwad and M. A. Anuse, Indian J. Chem. Technol., 10, 447 (2003).

42. S. H .Gaikwad, D. S. Bhange and M. A. Anuse, Revue Roumaine de Chimie, 49, 631 (2004).

43. S. H. Gaikwad, T. N .Lokhande and M. A. Anuse, Indian J. Chem., 44A, 1625 (2005).

44. K. S. Dhaka, J. Mohan, V. K. Chadha and H. K. Pujari, Indian J. Chem., 12, 288 (1974).

45. N. H. Furman, Standard Methods of Chemical Analysis, 6th edn; Robert E. Krieger publishing

DETERMINATION OF PALLADIUM(II) 
Company, Malabar, Florida, (1962).

46. G. S. Kamble, S. S. Kolekar and M. A. Anuse, Spetrochim. Acta Part A: Mol. Biomol. Spectrosc., 78, 1455 (2011).

47. G. H. Ayer, Anal. Chem., 21, 652 (1949).

48. E. B. Sandell, Colorimetric Determination of Traces of Metals, $3^{\text {rd }}$ edn; Interscience Publishers, New York, p-97 (1959).

49. B. Ramachandra and B. Narayana, J. Indian Chem. Soc., 77, 440 (2000).

50. S. A. Patil, B. M. Badiger, S. M. Kudari and V. H. Kulkarni, Transition Met. Chem., 8, 238 (1983).

51. A. B. Shaikh, U. B. Barache, M. A. Anuse and S. H. Gaikwad, S. Afr. J. Chem., 69, 157 (2016).

52. Z. Marckzenco, Spectrophotometric Determination of Trace Elements, 1st ed., Ellis Hardwood Ltd. John Wiley and Sons, Chinchester, (1976).

53. S. B .Zanje, A .N. Kokare, V. J. Suryavanshi, D. P. Waghmode, S. S. Joshi and M. A. Anuse, Spetrochim. Acta Part A: Mol. Biomol. Spectrosc., 169, 223 (2016).

[RJC-1804/2017] 